\title{
Glycine-induced cryotransformation of plasmids into Bacillus anthracis
}

\author{
Alexey S. Stepanov, ${ }^{1 *}$ Olga B. Puzanova, ${ }^{1}$ Stanislav Ya. Dityatkin, ${ }^{2}$ Olga G. Loginova ${ }^{2}$ \\ and BORIS N. ILYASHENKO ${ }^{2}$ \\ ${ }^{1}$ Laboratory of Isotope Analysis, All-Union Antiplague Research Institute 'Microbe', 46 Universitetskaya, \\ Saratov 410071, USSR \\ ${ }^{2}$ Laboratory of Molecular Microbiology, Gamaleya Institute for Epidemiology and Microbiology, 18 Gamaleya Street, \\ Moscow 123098, USSR
}

(Received 3 October 1989; revised 6 February 1990; accepted 5 March 1990)

\begin{abstract}
Different cloning vectors (pC194, pBC16, pUB110, pBD10, pBD8, pAM 31 ) and Bacillus anthracis plasmid pX02 were introduced into $B$. anthracis by a transformation method. To induce an artificial competence state for uptake of isolated plasmid DNA, the cultures were treated with glycine, to reduce cross-linking of peptidoglycan, followed by freezing and thawing. The procedure is extremely rapid and relatively efficient (maximum transformation efficiency about $10^{3}$ c.f.u. per $\mu \mathrm{g}$ DNA) and allows different cloning vectors with molecular masses ranging from 1.8 to 17.7 MDa to be introduced into $B$. anthracis.
\end{abstract}

\section{Introduction}

Bacillus anthracis, the causative agent of anthrax, is pathogenic to domestic animals and humans. The virulence of this organism is associated with two separate plasmids, pX01 (110 MDa) and pX02 (60 MDa), which code for a trimeric toxin (Tox) and the production of a poly-D-glutamic capsule (Cap), respectively. The genes coding for toxin and capsule synthesis have been cloned in Escherichia coli and Bacillus subtilis (Vodkin \& Leppla, 1983; Robertson \& Leppla, 1986; Ivins \& Welkos, 1986; Tippets \& Robertson, 1988; Makino et al., 1988). However, the expression and toxicity of the cloned genes in a homologous system have not yet been examined because of the lack of a method for reintroducing them into $B$. anthracis.

Different experimental approaches have been used to introduce plasmids into B. anthracis. Ruhfel et al. (1984) and Stepanov et al. (1989), respectively, demonstrated the utility of transducing phages CP51 and CP54ant in transferring plasmids among $B$. anthracis, Bacillus thuringiensis and Bacillus cereus. Thorne's group showed the conjugative-like mobilization of large (pX01 and pX02) and small (pBC16) plasmids mediated by $B$. thuringiensis fertility plasmids of the $\mathrm{Cry}^{+}$family (Thorne, 1985; Battisti et al., 1985; Reddy et al., 1987). The involvement of Tn4430, located on one of these plasmids, pX012, in mobilization of pX01 and pX02 was demonstrated (Green et al., 1989). This group also used the cryptic plasmid pLS20 to transfer the small cloning vector plasmids pBC16 and pUB110 among a wide variety of Bacillus species including $B$. subtilis and $B$. anthracis (Koehler \& Thorne, 1987).

The anthrax bacillus is difficult to transform. To overcome this problem, $\mathrm{N}$-acetylmuramidase-induced protoplast transformation (Makino et al., 1987) and an electroporation method (Bartkus \& Leppla, 1989) have recently been developed. It was also shown by Heierson et al. (1987) that $B$. thuringiensis, which is taxonomically very close to $B$. anthracis, could be transformed by plasmid DNA with a high degree of efficiency using the Tris-alkaline procedure first described for Bacillus brevis by Takahashi et al. (1983).

In this paper we report a two-step procedure for the introduction of cloning vectors into $B$. anthracis.

\section{Methods}

Strains, phages and plasmids. These are listed in Table 1. B. anthracis strain Sterne 34F2 was used as the recipient unless otherwise indicated.

Media and growth conditions. Brain heart infusion (BHI) broth and solidified agar medium (Difco) were routinely used unless otherwise noted.

Recipient strains were grown overnight without shaking in $250 \mathrm{ml}$ Erlenmeyer flasks containing $25 \mathrm{ml} \mathrm{BHI}$ broth at $37^{\circ} \mathrm{C}$.

Transformation procedure. To $25 \mathrm{ml}$ of an overnight culture of the recipient in BHI broth, glycine (Serva) and $\mathrm{MgCl}_{2}$ (Merck) were added to final concentrations of $5 \%(\mathrm{w} / \mathrm{v})$ and $0.05 \mathrm{M}$, respectively, and incubation was continued with gentle shaking at $37^{\circ} \mathrm{C}$ for $2.5 \mathrm{~h}$. Then the cells were sedimented in a bench-top centrifuge (Sigma 202MK) 
Table 1. Bacterial strains, phage and plasmids

\begin{tabular}{|c|c|c|}
\hline & Phenotype & Reference or source \\
\hline \multicolumn{3}{|l|}{$\begin{array}{l}\text { Strains } \\
\text { B. anthracis }\end{array}$} \\
\hline Sterne $34 \mathrm{~F} 2$ & $\mathrm{Tox}^{+}\left(\mathrm{pXO1}{ }^{+}\right) \mathrm{Cap}^{-}(\mathrm{pX02}-)$ & Culture collection of \\
\hline KM33 & $\mathrm{Tox}^{-}(\mathrm{pX01}-) \mathrm{Cap}^{-}(\mathrm{pX02}-)$ & the All-Union \\
\hline KM34 & $\mathrm{Tox}^{-}\left(\mathrm{pX} 01^{-}\right) \mathrm{Cap}^{+}\left(\mathrm{pX} 02^{+}\right)$ & Antiplague Research \\
\hline KM35 & $\mathrm{Tox}^{+}(\mathrm{pX01}+) \mathrm{Cap}^{-}\left(\mathrm{pX02}^{-}\right)$ & Institute 'Microbe' \\
\hline Phage & & Thorne (1978) \\
\hline \multicolumn{3}{|l|}{ Plasmids } \\
\hline pC194 (1.8 MDa) & $\mathrm{Cm}^{\mathrm{r}}$ & Ehrlich (1977) \\
\hline pBC16 (2.8 MDa) & $\mathrm{Tc}^{r}$ & Bernhard et al. (1978) \\
\hline pUB110 (2.8 MDa) & $\mathrm{Km}^{\mathrm{r}}$ & Gryczan et al. (1978) \\
\hline pBD10 (4.4 MDa) & $\mathrm{Cm}^{\mathrm{r}} \mathrm{Em}^{\mathrm{r}}$ & $\begin{array}{l}\text { Bacillus Genetic } \\
\text { Stock Center (Ohio } \\
\text { State University) }\end{array}$ \\
\hline pBD8 (6.0 MDa) & $\mathrm{Km}^{r} \mathrm{Cm}^{r}$ & \\
\hline pAM $\beta 1(17.7 \mathrm{MDa})$ & $\mathbf{M L S}^{\mathbf{r}}$ & Clewell et al. (1974) \\
\hline pX02 (60.0 MDa) & $\mathrm{Cap}^{+}$ & This laboratory \\
\hline
\end{tabular}

and resuspended to a final density of $1-2 \times 10^{9}$ viable cells $\mathrm{ml}^{-1}$ in a solution containing, unless otherwise specified, $0.3 \%(\mathrm{w} / \mathrm{v})$ Bactopeptone (Spofa), $5 \%(\mathrm{w} / \mathrm{v})$ glycine, $10 \%(\mathrm{w} / \mathrm{v})$ polyethylene glycol 6000 (PEG 6000; Serva) and 0.1 M-MgCl 2 . Samples $(150 \mu \mathrm{l})$ were transferred to glass tubes and combined with $50 \mu \mathrm{l}$ DNA in $1 \mathrm{~mm}$-Tris/HCl buffer ( $\mathrm{pH} 7 \cdot 4$ ). The samples (total volume $200 \mu \mathrm{l}$ each) were frozen by immersion in liquid nitrogen for 3 min unless otherwise noted, then thawed at temperatures described in the text (commonly at $37^{\circ} \mathrm{C}$ ). Finally the cells were transferred to $1 \mathrm{ml} \mathrm{BHI}$ broth, incubated at $37^{\circ} \mathrm{C}$ with gentle shaking for $2 \mathrm{~h}$, then plated on selective solid media and incubated at $37^{\circ} \mathrm{C}$ for $24-36 \mathrm{~h}$.

Viability was estimated by plating dilutions in $0.85 \%(\mathrm{w} / \mathrm{v}) \mathrm{NaCl}$ on non-selective medium after freezing and thawing.

The sterility of isolated DNA was checked by plating the initial solution on BHI agar plates followed by incubation at $37^{\circ} \mathrm{C}$ for $48 \mathrm{~h}$. The specificity of transformation was verified by addition to the freezing mixture of DNAase (Amersham) to a final concentration of $5 \mu \mathrm{g} \mathrm{ml}^{-1}$.

Selection of transformants was performed on BHI agar plates supplemented with one of the following antibiotics: chloramphenicol $\left(20 \mu \mathrm{g} \mathrm{ml}^{-1}\right)$, tetracycline $\left(10 \mu \mathrm{g} \mathrm{ml}^{-1}\right)$, kanamycin $\left(50 \mu \mathrm{g} \mathrm{ml}^{-1}\right)$ and erythromycin $\left(10 \mu \mathrm{g} \mathrm{ml}^{-1}\right)$. $\mathrm{Cap}^{+}\left(\mathrm{pX02}^{+}\right)$transformants were selected by treatment with phage CP54 according to Green et al. (1985).

The main parameters for cryotransformation were determined with supercoiled DNA of plasmid pBD10. The other plasmids used were pC194, pBC16, pBD8, pUB110, pAM $\beta 1$ and pX02, prepared in caesium chloride gradients according to the method of Mozharov (1982).

\section{Results}

The various parameters of the transformation protocol were tested in turn.

\section{Effect of glycine}

Glycine concentrations from 1 to $10 \%$ were tested, with incubation for $2.5 \mathrm{~h}$. Incubation with glycine at concentrations between 3 and $6 \%$ gave the maximum yield of transformants (Table $2 a$ ). The concentrations of glycine used did not lead to protoplast formation or sensitivity to osmotic shock.

\section{Effect of divalent cations}

Dityatkin et al. (1985) reported a dependence of the transformation frequency of $E$. coli on the concentration of divalent cations in the freezing mixture. A significant effect of $\mathrm{Mg}^{2+}$ on the yield of B. anthracis transformants was observed (Table $2 b$ ). The optimum concentration of $\mathrm{Mg}^{2+}$ was $0 \cdot 1-0 \cdot 15 \mathrm{M}$. Transformation of B. anthracis was also achieved by freeze-thawing in the presence of $\mathrm{CaCl}_{2}$, although this was rather less efficient than transformation in the presence of $\mathrm{MgCl}_{2}$ (Table $2 b$ ).

\section{Effect of PEG 6000}

An approximately 20-fold increase in the yield of transformants was observed when $10 \%$ (w/v) PEG was added to the freezing mixture. The other concentrations of PEG used were less effective (Table $2 c$ ).

\section{Effect of freezing medium}

Distilled water, LB, 2YT and Chottinger broth, and 0.3$1.0 \%$ solutions of Bacto-peptone were used, all other conditions being equal. The maximum yield of transformants was observed when distilled water or any concentration of Bacto-peptone were used. (Table $2 d$ ).

\section{Freezing-thawing conditions}

Freezing at $-196^{\circ} \mathrm{C}$ (liquid nitrogen for $3 \mathrm{~min}$ ) and $-12{ }^{\circ} \mathrm{C}$ (deep freeze for $25 \mathrm{~min}$ ) were compared. No 
Table 2. Effect of altering parameters of freeze-thaw transformation

For details of individual treatments see Results. All results are means of at least five experiments; in no case did the replicates vary by more than twofold.

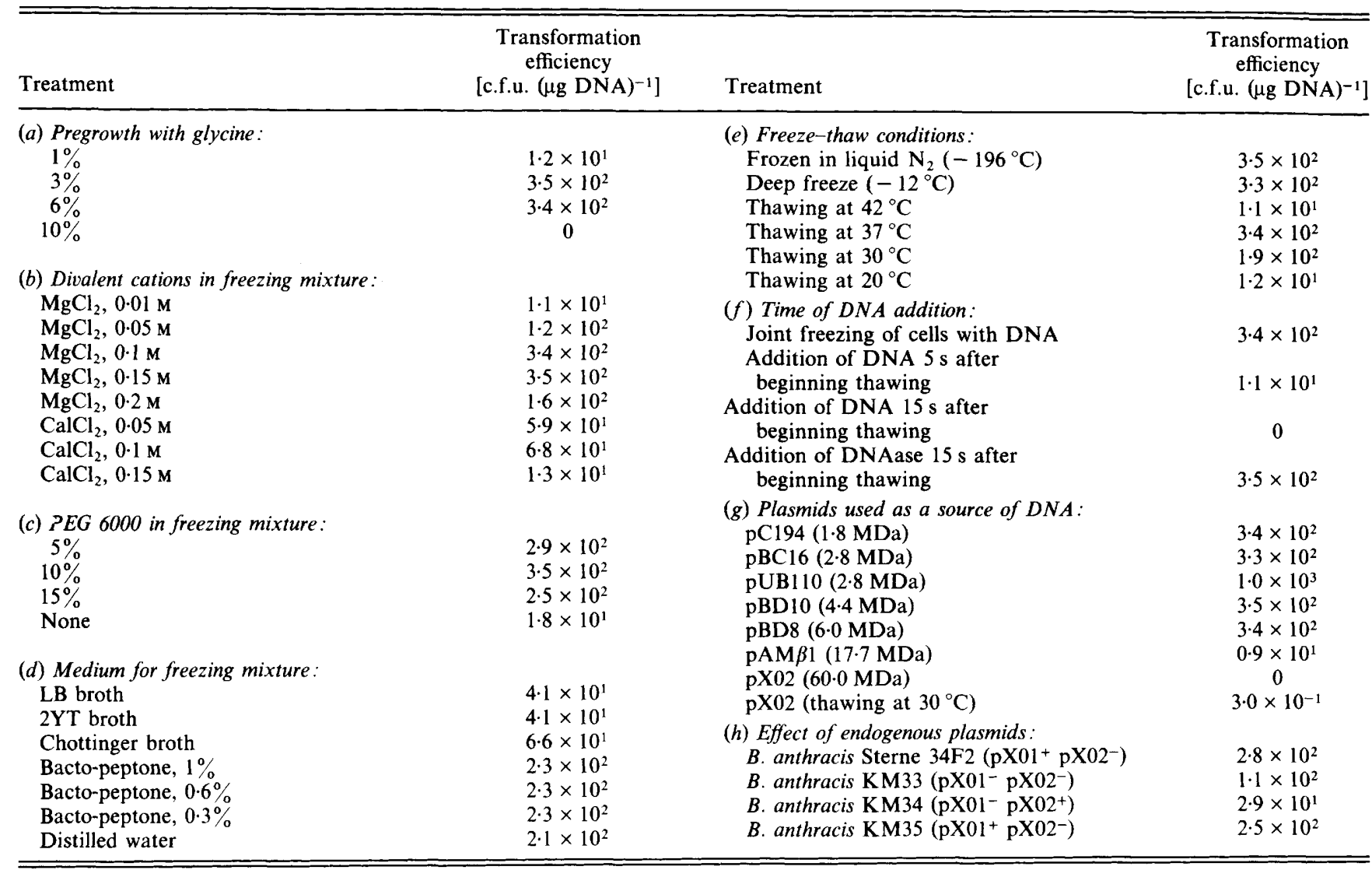

significant effect of freezing temperature was found (Table 2e).

When the thawing temperature was varied from 42 to $30^{\circ} \mathrm{C}$, the maximum yield of transformants occurred at $37^{\circ} \mathrm{C}$ (Table $2 e$ ). The only exception was transformation of $B$. anthracis with the homologous high-molecular-mass plasmid pX02, which occurred only when the thawing temperature was reduced to $30^{\circ} \mathrm{C}$ (Table $2 g$ ).

\section{Duration of the competence state}

The cells were frozen in the absence of plasmid DNA, and DNA was added at various times after initiation of thawing at $37^{\circ} \mathrm{C}$. The induced competence state of the recipient cells was rapidly lost during thawing: the susceptibility of the bacteria to exogenous DNA was completely lost within $15 \mathrm{~s}$. The maximum yield of transformants was observed only if the recipient cells were frozen in the presence of DNA. The addition of
DNAase to the incubation mixture after $15 \mathrm{~s}$ incubation at $37^{\circ} \mathrm{C}$ did not result in a reduction of transformation efficiency, confirming the transient nature of the competence state (Table $2 f$ ).

\section{Effect of plasmid size}

Merrick et al. (1987) reported a reduction of cryotransformation with increasing plasmid size in both $E$. coli and Klebsiella pneumoniae. An increase of plasmid molecular mass from 1.8 to $6.0 \mathrm{MDa}$ had no significant effect on freeze-thaw transformation frequency in $B$. anthracis. However, the larger plasmids of 17.7 and 60.0 MDa transformed with significantly lower efficiency (Table $2 g$ ).

Additional proof of the introduction of plasmids into $B$. anthracis cells was obtained in transformation experiments performed with plasmid DNA reisolated from transformants (data not shown). 


\section{Effect of endogenous plasmids}

The isogenic derivatives of virulent strain 81/1 (KM33, KM34, KM35) were used in these experiments. The carriage of plasmid pX01 did not affect the frequency of transformation, but the yield of transformants decreased approximately tenfold when strain KM34, harbouring plasmid $\mathrm{pX} 02$, was used as recipient (Table $2 h)$.

\section{Discussion}

Since Dityatkin et al. (1972) first used the procedure of freeze-thawing for transformation of E. coli and Proteus vulgaris, cryotransformation has been shown to be useful for induction of DNA uptake by Agrobacterium tumefaciens (Holsters et al., 1978), Bordetella pertussis (Weiss \& Falkow, 1982), Yersinia pestis (Kokoushkhin, 1982), $K$. pneumoniae and Proteus mirabilis (Merrick et al., 1987), and B. cereus (Loginova \& Dityatkin, 1988).

We have now shown that cryotransformation can be used to induce plasmid DNA uptake in B. anthracis. Because of its rapidity and simplicity, cryotransformation is more attractive than the recently described method of Makino et al. (1987), involving the transformation in $N$-acetylmuramidase-induced protoplasts.

DNA uptake by $B$. anthracis in the conditions described by Dityatkin et al. (1972) for $E$. coli and $P$. vulgaris (i.e. a low $\mathrm{MgCl}_{2}$ concentration $-10.0 \mathrm{mM}$ - and the absence of treatment with glycine and PEG) was not observed in our experiments (data not shown).

Hammes et al. (1973) showed that incorporation of glycine into cell wall peptidoglycan reduces the degree of cross-linking. We therefore examined the effect of glycine treatment on induction of competence in $B$. anthracis prior to freeze-thawing. Incubation of a growing culture for $2.5 \mathrm{~h}$ with glycine at a concentration of 3-6\% was necessary to obtain transformants.

Other components known to enhance transformation efficiency were also tested. An increase of DNA uptake was observed when $\mathrm{Mg}^{2+}(0 \cdot 1-0 \cdot 15 \mathrm{M})$ was added to the freezing mixture. Transformation in the presence of $\mathrm{Ca}^{2+}$ was considerably less efficient. The addition of PEG 6000 to the freezing mixture to a final concentration of $10 \%$ was essential for efficient DNA uptake.

In agreement with the results of Dityatkin et al. (1985) with $E$. coli $\mathrm{HB} 101$, one of the features of $B$. anthracis as a recipient of the cryotransformation system was its shortterm receptibility to DNA. However, an increase of transformation frequency of $B$. anthracis with decreasing temperature of freezing was not demonstrated. The lack of a significant effect of freezing temperature on transformation efficiency is in agreement with results reported by Merrick et al. (1987) for K. pneumoniae.
Dityatkin et al. (1985) showed that deviation of the thawing temperature in either direction from the optimum $\left(42^{\circ} \mathrm{C}\right)$ progressively reduced the maximum yield of $E$. coli transformants. Unlike $E$. coli, the maximum efficiency of transformation for $B$. anthracis was observed at $37^{\circ} \mathrm{C}$. The effect of thawing temperature was particularly noticeable when transformation was performed with homologous DNA of high molecular mass, e.g. plasmid pX02. It was necessary to decrease the temperature of thawing from 37 to $30{ }^{\circ} \mathrm{C}$ to obtain $\mathrm{Cap}^{+}$ transformants.

Thus our cryotransformation procedure may be a convenient tool for examination of cloned virulenceassociated genes in a homologous system, for elucidation of their roles in pathogenesis of $B$. anthracis.

\section{References}

BartKus, J. M. \& LePPla, S. H. (1989). Transcriptional regulation of the protective antigen gene of Bacillus anthracis. Infection and Immunity 57, 2295-2300.

Battisti, L., Green, B. D. \& Thorne, C. B. (1985). Mating system for transfer of plasmids among Bacillus anthracis, Bacillus cereus, and Bacillus thuringiensis. Journal of Bacteriology 162, 543-550.

Bernhard, K., SCHREmpF, H. \& Goebel, W. (1978). Bacteriocin and antibiotic resistance plasmids in Bacillus cereus and Bacillus subtilis. Journal of Bacteriology 133, 897-903.

Clewell, D. B., Yagi, Y., Dunny, G. \& Schultz, S. (1974). Characterization of three plasmid DNA molecules in a strain of Streptococcus faecalis. Identification of a plasmid determining erythromycin resistance. Journal of Bacteriology 117, 283-289.

Dityatkin, S. Ya., Lisovskaya, K. V., Panzava, N. N. \& IlyaSHENKO, B. N. (1972). Frozen-thawed bacteria as recipients of isolated coliphage DNA. Biochimica et Biophysica Acta 281, 319-323.

Dityatkin, S. YA., Loginova, O. G., Kim, A. A. \& Ilyashenko, B. N. (1985). Cryotransformation and cryotransfection of bacteria. Cryo Letters 6, 67-72.

EHRLICH, S. D. (1977). Replication and expression of plasmids from Staphylococcus aureus in Bacillus subtilis. Proceedings of the National Academy of Sciences of the United States of America 74, 1680-1682.

Green, B. D., Battisti, L., Koehler, T. M., Thorne, C. B. \& Ivins, B. E. (1985). Demonstration of capsule plasmid in Bacillus anthracis. Infection and Immunity 49, 291-297.

Green, B. D., Battisti, L. \& Thorne, C. B. (1989). Involvement of Tn4430 in transfer of Bacillus anthracis plasmids mediated by Bacillus thuringiensis plasmid pX012. Journal of Bacteriology 171, 104-113.

Gryczan, T. J., Contente, S. \& Dubnau, D. (1978). Characterization of Staphylococcus aureus plasmids introduced by transformation into Bacillus subtilis. Journal of Bacteriology 134, 318-329.

Hammes, W., Schleifer, K. N. \& Kandler, O. (1973). Mode of action of glycine on biosynthesis of peptidoglycan. Journal of Bacteriology 116, 1029-1053.

Heierson, A., Landen, R., Lövgren, A., Dalhammar, G. \& Boman, H. G. (1987). Transformation of vegetative cells of Bacillus thuringiensis by plasmid DNA. Journal of Bacteriology 169, 11471152.

Holsters, M., De Waele, D., Depieker, A., Messens, E., van MONTAGU, M. \& SCHELl, J. (1978). Transfection and transformation of Agrobacterium tumefaciens. Molecular and General Genetics 163, 181-187.

IVINS, B. \& Welkos, S. L. (1986). Cloning and expression of the Bacillus anthracis protective antigen in Bacillus subtilis. Infection and Immunity 54, 537-542. 
KOEHLER, T. M. \& THORNE, C. B. (1987). Bacillus subtilis (natto) plasmid pLS20 mediate interspecies plasmid transfer. Journal of Bacteriology 169, 5271-5278.

KoKousHKHIN, A. M. (1982). Transformation of plague microbe with DNA of homologous plasmids. In Molecular Biology and Genetics of Particularly Dangerous Infectious Pathogens, part 2, pp. 34-40. Saratov, USSR: All-Union Antiplague Research Institute 'Microbe' (in Russian)

Loginova, O. G. \& Dityatkin, S. YA. (1988). Cryotransformation of Bacillus cereus by plasmid DNA. Molecular Genetics, Microbiology and Virology 11, 44-48.

Makino, S., Sasakawa, C., Uchida, I., Terakado, N. \& Yoshikava, M. (1987). Transformation of a cloning vector, pUB110, into Bacillus anthracis. FEMS Microbiology Letters 44, 45-48.

Makino, S., Sasakava, O., Uchida, S., Terakado, N. \& Yoshikawa, M. (1988). Cloning and $\mathrm{CO}_{2}$-dependent expression of the genetic region for encapsulation from Bacillus anthracis. Molecular Microbiology 2, 371-376.

Merrick, M. J., Gibbins, J. R. \& Postgate, J. R. (1987). A rapid and efficient method for the plasmid transformation of Klebsiella pneumoniae and Escherichia coli. Journal of General Microbiology 133, 2053-2057.

MozHaRov, O. T. (1982). Optimization of extraction of homologous plague microbe plasmids. In Molecular Biology and Genetics of Particularly Dangerous Infectious Pathogens, part 1, pp. 48-52. Saratov, USSR: All-Union Antiplague Research Institute 'Microbe' (in Russian).

REDDY, A., BATTISTI, L. \& ThORNE, C. B. (1987). Identification of selftransmissible plasmids in four Bacillus thuringiensis subspecies. Journal of Bacteriology 169, 5263-5270.
Robertson, D. L. \& LePPLA, S. H. (1986). Molecular cloning and expression in Escherichia coli of the lethal factor gene of Bacillus anthracis. Gene 44, 71-78.

RuHFel, R. E., RoBillard, N. J. \& Thorne, C. B. (1984). Interspecies transduction of plasmids among Bacillus anthracis, B. cereus, and $B$. thuringiensis. Journal of Bacteriology 157, 708-711.

Stepanov, A. S., Gavrilov, S. V., Puzanova, O. B., Grigoryeva, T. M. \& AzIzBEKYAN, R. R. (1989). Transduction of plasmids in Bacillus anthracis by bacteriophage CP54ant. Molecular Genetics, Microbiology and Virology 1, 14-19.

Takahashi, W., Yamagata, H., Yamaguchi, K., Tskukagoshi, N. \& UDAKA, S. (1983). Genetic transformation of Bacillus brevis 47, a protein secreting bacterium, by plasmid DNA. Journal of Bacterio$\log y$ 156, 1130-1134.

Thorne, C. B. (1978). Transduction in Bacillus thuringiensis. Applied and Environmental Microbiology 35, 1109-1115.

THORNE, C. B. (1985). Genetics of Bacillus anthracis. In Microbiology1985, pp. 56-62. Edited by L. Leive. Washington DC: American Society for Microbiology.

TIPPETS, M. T. \& ROBERTSON, D. L. (1988). Molecular cloning and expression of Bacillus anthracis edema factor toxin gene: a calmodulin-dependent adenylate cyclase. Journal of Bacteriology 170, 2263-2266.

VoDKIN, M. H. \& LEPPLA, S. H. (1983). Cloning of protective antigen gene of Bacillus anthracis. Cell 34, 693-697.

WeIss, A. A. \& Falkow, S. (1982). Plasmid transfer to Bordetella pertussis: conjugation and transformation. Journal of Bacteriology 152, 549-552. 